\title{
PENGGUNAAN WEB UNTUK MENINGKATKAN KUALITAS KERJA PEGAWAIPADA PEMERINTAH DAERAH KABUPATEN TANGERANG
}

\author{
Ulis Bella \\ Ruli Supriati \\ Program Pasca Sarjana, Jurusan Magister Teknik Informatika \\ Perguruan Tinggi Raharja, Jl.Jenderal Sudirman No. 40 \\ Modern Cikokol Tangerang \\ E-mail:ulis.bella@raharja.info, \\ ruli@raharja.info
}

\begin{abstract}
Technological current developments more rapidly, many users to improve of information technology the way of delivering information in various ways, one of them with the website. in technology advances especially in the field of information and communication has encouraged globalization in the office and the more it needs new information, where the information is easy in the can by using web technology, namely the Internet, where information needs to be better in terms of speed, capacity and sophistication in providing information. Many people have realized that the web is not just a mere web page, but also can interact with visitors. The web has become a user interface for database applications, and Web information systems have become scattered, nowadays almost anyone can do accessing information over the web. As well as the Tangerang District Government will improve system performance through running. Likewise in the warehouse that is not computerized Web -based, but still using Microsoft excel, so that the warehouse often experience difficulties and delays in processing the data and create reports. With the web-based goods inventory system, is expected to help users interested in parts warehouse Revenue Office Tangerang District Government, and effectiveness in many ways.
\end{abstract}

\section{ABSTRAKSI}

Perkembangan teknologi saat ini semakin pesat, sehingga banyak pengguna teknologi informasi memperbaiki cara penyampaian informasi dengan berbagai macam cara, salah satunya dengan website. Kemajuan teknologi khususnya dibidang informasi dan komunikasi telah mendorong arus globalisasi di perkantoran dan semakin dibutuhkannya informasi-informasi yang baru, dimana informasi itu mudah di dapat dengan menggunakan teknologi internet yaitu web, dimana kebutuhan informasi menjadi lebih baik dari segi kecepatan, kemampuan dan kecanggihan dalam memberikan suatu informasi. Banyak orang telah menyadari bahwa $\mathrm{Web}$ bukan hanya sekedar halaman situs belaka, namun juga dapat berinteraksi dengan pengunjungnya. Web telah menjadi antar muka pemakai untuk aplikasi basis data, dan Web telah menjadi sistem informasi yang tersebar, Saat ini hampir semua orang dapat melakukan pengaksesan informasi melalui web. Seperti halnya Pemda Kabupaten Tangerang yang akan meningkatkan kinerja melalui sistem yang berjalan. Begitupun pada bagian gudang yang belum terkomputerisasi berbasis Web, melainkan masih menggunakan microsoft excel, sehingga bagian gudang sering mengalami kesulitan dan keterlambatan dalam mengolah data maupun membuat laporan. Dengan adanya sistem Persediaan barang berbasis web, diharapkan dapat membantu user yang berkepentingan dalam bagian gudang Dinas Pendapatan Daerah Pemda Kabupaten Tangerang, dan efektifitas dalam banyak hal. 
Kata kunci : sistem, informasi, persediaan barang, berbasis web 


\subsection{LatarBelakang}

\section{I.Pendahuluan}

Perkembangan teknologi yang pesat saat ini banyak menarik perhatian masyarakat luas, dengan bergesernya era manualisasi ke era komputerisasi yang memudahkan penggunanya dalam melakukan berbagai aktifitas / kegiatan perkuliahan, perkantoran, pendidikan, dan lain sebagainya. Perkembangan komputer yang terus dinamis diiringi perkembangan zaman, semakin membutuhkan informasi yang cepat dan akurat dan tidak memerlukan waktu yang lama dalam menggali informasi yang dibutuhkan. Mulai dari sebuah perkantoran yang menggunakan komputer untuk sebuah sistem informasi yang berguna untuk perusahaan tersebut, dalam menyelesaikan semua pekerjaan yang ada, seperti menyimpan semua berkasberkas penting sampai pembuatan laporan.

Pada saat ini banyak pemerintah daerah sedang melakukan perbaikan di dalam sistem perkantoran yang manual menjadi terkomputerisasi. Salah satunya pada Dinas Pendapatan Daerah Pemerintah Daerah Kabupaten Tangerang yang sedang melakukan perbaikan pada manajemen yang sudah ada. Dengan tujuan meningkatkan kinerja sistem pelayanan kepada stakeholder, karena sistem informasi yang berjalan saat ini belum memenuhi standar kepuasan, baik dari segi waktu, segi kualitas maupun dari segi laporan, karena laporan merupakan pendukung bagi manajemen dalam pengambilan keputusan.

Saat ini Pemerintah Daerah Kabupaten Tangerang masih perlu melakukan perbaikan kinerja dalam mengelola sistem persediaan barang khususnya pada Dinas Pendapatan Daerah. Permasalahan yang dialami saat ini belum terkontrolnya barang yang masuk maupun keluar, sistem yang digunakan dalam pemasukan data masihmenggunakan Ms. Excel dan belum dapat memberikan penyampaian informasi yang di butuhkan oleh stakeholder. Dengan melihat situasi informasi persediaan alat tulis kantor pada Dinas Pendapatan Daerah saat ini, menjadikan sistem informasi tersebut belum efektif dalam melakukan proses pemasukan data.

Untuk memecahkan masalah tersebut makapenulis merancang suatu sistem yang dapat memberikan informasi persediaan barang secara realtime dan dapat bekerja secara efektif. Tujuan dari pembuatan sistem ini tidak lain untuk dapat melakukan proses pemasukan data barang secara efisien. Penggunaan sistem ini semakin dibutuhkan sejalan dengan kebutuhan pihak Dinas Pendapatan Daerah akan informasi persediaan barang.

\subsection{Rumusan Masalah}

Berdasarkan latar belakang yang ada di atas yang telah dijelaskan maka, penulis merumuskan beberapa masalah sebagai berikut:

1. Sistem persediaan barang yang berjalan saat ini belum terkontrol dengan baik.

2. Pemasukan data persediaan barang pada Dinas Pendapatan Daerah belum terkomputerisasi dengan baik.

3. Sistem yang sudah berjalan saat ini belum dapat memberikan informasi yang dibutuhkan oleh stakeholder.

\subsection{Tujuan dan Manfaat Penelitian Tujuan Penelitian}

Penulis mengelompokkan beberapa tujuan di antaranya sebagai berikut:

$$
\begin{array}{lr}
\text { Untuk memberikan } \\
\text { alternatif pada Dinas } \\
\text { Pendapatan Daerah } \\
\text { Kabupaten Tangerang dari } \\
\text { masalah yang ada, seperti }
\end{array}
$$


dalam pemasukan data, pengontrolan barang yang masuk maupun keluar.

2. Untuk mempermudah pegawai Dinas Pendapatan Daerah Kabupaten Tangerang, agar terciptanya kinerja yang efisien.

\section{Manfaat Penelitian}

Penelitian ini diharapkan dapat mempunyai berbagai manfaat, antara lain sebagai berikut :

1. Memudahkan Dinas Pendapatan Daerah Kabupaten Tangerang dalam mendapatkan informasi yang akurat mengenai sistem informasi persediaan barang.

2. Sistem informasi persediaan barang ini dapat memudahkan pegawai Dinas Pendapatan Daerah Kabupaten Tangerang untuk dapat melakukan proses pemasukan data dan penyampaian informasi secara efisien.

\subsection{Metodologi Penelitian}

Untuk mendapatkan data yang diperlukan dalam penelitian tersebut maka, penulis mengumpulkan beberapa metode sebagai berikut:

\section{Metode Analisa Kebutuhan Pengumpulan Data}

1. Observasi

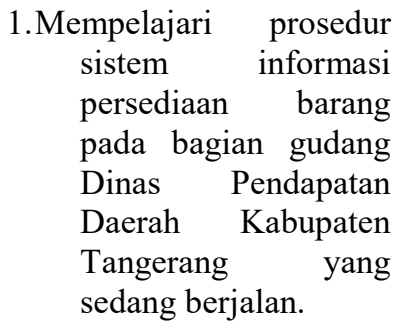

2.Menganalisa sistem yang sedang berjalan untuk di implementasikan menjadi rancangan web.

\section{Wawancara}

Metode $\begin{array}{r}\text { dimana } \\ \text { memberikan }\end{array}$
peneliti kertanyaan kepada pihak-
pertang
pihak yang terkait tentang
permasalahan yang ada
atau sistem yang sudah
berjalan saat ini, dengan
melakukan tanya jawab
terhadap pihak-pihak yang
terkait tersebut untuk
mendapatkan data.

\section{Studi Pustaka}

Penulis

mencari

bahan-bahan dengan membaca buku yang berisi teori-teori yang berkaitan dengan permasalahan yang dibahas pada penelitian yang penulis sedang teliti saat ini.

\section{Metode Analisa Data}

Analisa sistem dilakukan dengan melalui 4 (empat) tahapan yaitu : survei sistem yang sedang berjalan, analisa terhadap temuan survei, identifikasi kebutuhan informasi dan identifikasi persyaratan sistem.

\section{Metode Perancangan}

Perancangan istem informasi persediaan barang berbasis web pada Dinas Pendapatan Daerah menggunakan beberapa software dalam perancangannya, antara lain :

1. PHP, merupakan bahasa pemrograman yang akan dipakai.

2. MySQL, merupakan database yang akan digunakan.

3. Macromedia

Dreamweaver, merupakan software yang digunakan untuk mendesign web yang akan dibuat.

4. UML, merupakan software yang digunakan untuk merancang sistem dengan Use Case Diagram, Sequence Diagram, Activity Diagram, State 


\section{Diagram dan Class Diagram.}

\section{Landasan Teori}

\subsection{Definisi Perancangan Sistem}

Menurut Edi Purwono (2002 :

12) Perancangan sistem merupakan kegiatan untuk pengembangan sistem dan prosedur baru, dalam kaitannya dengan sasaran-sasaran baru yang dikehendaki oleh pihak manajemen, untuk memperoleh suatu sistem informasi, yang mampu dipakai untuk memanajemen perusahaannya secara lebih efektif dan efisien.

\subsection{Pengertian Sistem}

Definisi sebuah sistem mempunyai peranan yang sangat penting di dalam pendekatan untuk mempelajari sebuah sistem.Pendekatan sistem yang merupakan kumpulan dari elemenelemen, komponen-komponen, dan sub-sub sistem merupakan definisi yang lebih luas.

\subsection{Definisi Informasi}

Informasi adalah bahan pokok dalam pemberitaan, informasi bukan hanya fakta/kenyataan melainkan lebih luas lagi tentang proses dan penggunaan informasi itu sendiri. Informasi ini harus bergerak, mudah dimengerti, utuh, dan bulat.

\subsection{Dinas pendapatan daerah}

Menurut Peraturan Bupati Tangerang (Nomor 24 Tahun 2008), Dinas Pendapatan Daerah adalah suatu bagian dari Kabupaten Tangerang yang mempunyai fungsi:

$$
\text { Menyusun bahan }
$$

kebijaksanaan teknis dibidang pendapatan daerah

b. Pengumpulan dan pengolahan bahan untuk penyusunan, rencana dan program kegiatan dibidang pendapatan.

c. Pelaksanaan penelitian, pengkajian, evaluasi, penggalian dan pengembangan pendapatan daerah.

\subsection{Kabupaten Tangerang}

Kabupaten Tangerang adalah wilayah Tingkat II di Tangerang setalah Kota Tangerang yang kantornya berpusat pada Pemerintahan Daerah Kabupaten Tangerang di Tigaraksa.

(modul bagian organisasi Setda Kab.Tangerang, 2008: 07)

\subsection{Konsep Dasar Sistem Informasi}

Menurut Jogiyanto H.M (2001 :

11) Sistem informasi merupakan suatu sistem dalam suatu organisasi untuk mempertemukan kebutuhan pengolahan transaksi harian, mendukung operasi, bersifat manajerial dan kegiatan strategi dari suatu organisasi dan menyediakan pihak luar tertentu dengan laporanlaporan yang diperlukan.

\subsection{Pengertian Website}

Web site (situs web) adalah merupakan alamat (URL) yang berfungsi sebagai tempat penyimpanan data dan informasi dengan berdasarkan topik tertentu (Sunartrihantono, Bimo, 2002 : 87).

Web adalah jaringan beriburibu komputer yang dikategorikan menjadi dua: client/server dengan menggunakan software khusus membentuk sebuah jaringan yang disebut jaringan client/server yang mempunyai fasilitas hipertext untuk menampilkan informasi atau data berupa teks, gambar, suara, animasi, dan data multimedia lainnya, yang diantara informasi atau data tersebut saling berhubungan satu sama lain (Sunartrihantono, Bimo, 2002 : 46).

$W e b$ dapat dikategorikan menjadi dua yaitu web statis dan web dinamis atau interaktif.Web Statis adalah web yang berisi/menampilkan informasi-informasi yang sifatnya statis (tetap), sedangkan web dinamis adalah web yang menampilkan informasi serta dapat berinteraksi dengan user yang sifatnya dinamis.

2.8

\section{Definisi}

Modeling (UML)

Dalam

melakukan 
menggunakan UML (Unified Modeling Language). Menurut Martin Fowler (2005 : 17) mendefinisikan Unified Modeling Language sebagai berikut : “ Salah satu alat bantu yang sangat handal di dunia pengembangan sistem yang berorientasi objek. "

Hal ini disebabkan karena UML menyediakan pemodelan visual yang memungkinkan bagi pengembang sistem untuk membuat cetak biru atas visi mereka dalam bentuk yang baku, mudah dimengerti serta dilengkapi dengan mekanisme yang efektif untuk berbagi (sharing) dan mengkomunikasikan rancangan mereka dengan yang lain.

UML merupakan standar yang relatif terbuka yang di kontrol oleh Object Management Group (OMG), sebuah konsorsium terbuka yang terdiri dari banyak perusahaan.Dimana OMG dibentuk untuk membuat standar-standar yang mendukung interoperabilitas, khususnya untuk sistem berorientasi objek.

\section{III.ANALISA SISTEM YANG BERJALAN}

\subsection{Gambaran Umum Objek Yang Diteliti}

Dewasa ini ilmu pengetahuan dan teknologi berkembang dengan cepat, terutama dalam bidang Teknologi Informatika. Teknologi komputer banyak diminati oleh masyarakat untuk memenuhi kebutuhan mereka, karena dengan menggunakan komputer para pengguna (user) dapat menyelesaikan urusan lebih cepat dan lebih efisien. Di daerah Tangerang ternyata hal tersebut masih belum bisa memenuhi kebutuhan masyarakat dalam memperoleh data secara komputerisasi di setiap bidang. Oleh karena itu Pemerintah Daerah Kabupaten Tangerang sebagai sentral kantor
Pemerintah di Kabupaten, berusaha meningkatkan sistem kerja yang sedang berjalan, khususnya pada Dinas Pendapatan Daerah.

Dunia komputer dan alat-alat canggih serta otomatis lainnya dalam dunia perkantoran, baik instansi pemerintah maupun swasta, sangat cepat sekali perkembangannya, sehingga selalu berubah setiap saat. Oleh karena itu Pemerintah Daerah Kabupaten Tangerang dalam pendiriannya mempunyai tujuan untuk meningkatkan kinerja yang lebih maju dalam menghadapi era globalisasi.

Pada saat ini Pemerintah Daerah Kabupaten Tangerang terdiri dari beberapa Dinas, salah satunya Dinas Pendapatan Daerah yang terletak di kantor Pemerintah Daerah Kabupaten Tangerang di Tigaraksa.

\subsection{Analisa Batasan Sistem}

Analisa batasan sistem yang dibahas disini mengenai persediaan barang yang ada di Dinas Pendapatan Daerah Pemda Kabupaten Tangerang yang mencakup proses pengajuan permintaan barang, pembelian barang sampai barang tersebut disimpan di stok gudang dan proses pelaporan persediaan barang yang ada di Dinas Pendapatan Daerah Pemda Kabupaten Tangerang, Adanya pengaturan hak user dengan menggunakan program berbasis web yang bisa mempermudah dalam pengerjaannya dengan tampilan yang menarik dan dimengerti.

\subsection{Urutan Prosedur}

Sistem Informasi persediaan barang yang ada di Dinas Pendapatan Daerah Pemda Kabupaten Tangerang dimulai dari Surat Permintaan Barang yang dibuat oleh bagian pengaju ke bagian gudang untuk diproses, apabila barang yang diminta ada di stok gudang maka barang tersebut langsung di keluarkan, dan apabila barang yang diminta tidak ada digudang maka langsung di buatkan Purchase Order, PO akan dikirim ke Pemasok untuk proses pembelian barang sesuai 
dengan pemesanan order. Pemasok akan mengirim barang dengan bukti surat jalan dan faktur. Selanjutnya barang tersebut disimpan di gudang dan langsung didistribusikan kepada bagian yang membutuhkan.

\subsection{Analisa Kontrol}

Pada proses yang berjalan, pengontrolannya perlu ditingkatkan karena masih ditemukan kendala yang menghambat seperti proses permintaan barang yang tiba-tiba, sedangkan barang yang diminta tidak ada digudang sehingga bagian gudang sering mengalami kesulitan dalam mengontrol stok minimal barang karena banyaknya barang yang ada di gudang.

Untuk menghindari kesalahan hasil laporan perlu adanya verifikasi dalam penginputan data agar hasilnya sesuai dengan yang diinginkan.

\subsection{Tata Laksana Sistem Yang Berjalan}

Untuk menganalisis sistem yang berjalan, pada penelitian ini digunakan program Unified Modeling Language (UML) untuk menggambarkan prosedur dan proses yang berjalan saat ini, pada penggambaran kali ini digunakan use case diagram yaitu sebagai berikut:

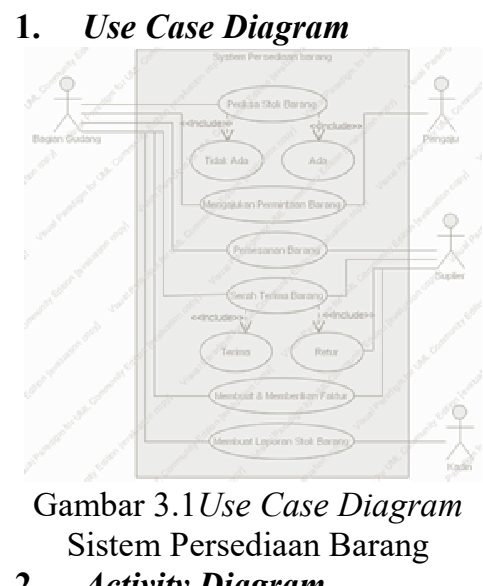

2. Activity Diagram

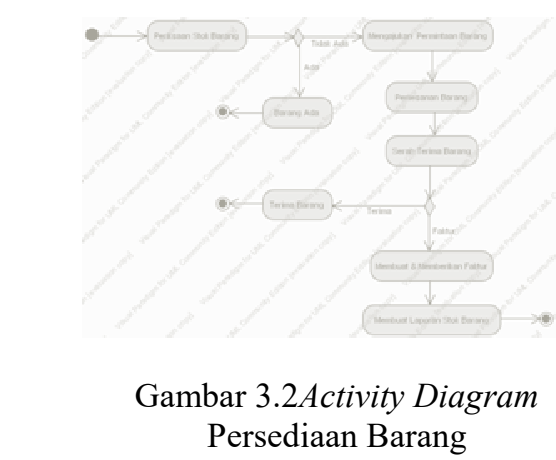

3. Sequence Diagram

Gambar 3.3Sequence Diagram Persediaan Barang

\subsection{Masalah Yang Dihadapi}

Seiring dengan banyaknya inventaris barang pada Dinas Pendapatan Daerah Pemda Kabupaten Tangerang, yang berbanding lurus dengan meningkatnya kebutuhan yang diperlukan oleh semua pegawainya membuat bagian staf barang sering mengalami kesulitan dalam mengontrol inventaris barang dan mengontrol stok minimal barang yang mengakibatkan staf gudang tidak mengetahui kapan harus membeli barang kembali. Karena sistem informasi persediaan barang yang masih menggunakan program aplikasi sederhana seperti Microsoft Excel.

Untuk mengatasi permasalah tersebut diatas, maka dibuatlah sistem informasi persediaan barang berbasis web pada bagian gudang yang bisa meminimalkan kesalahan dalam pengontrolan barang.

\subsection{Pemecahan Masalah}

Penulis akan membuat suatu program berbasis web yang bisa digunakan oleh bagian staf gudang untuk mengontrol stok minimal barang yang ada di gudang. Program tersebut akan menampilkan informasi yang dibutuhkan oleh bagian staf gudang seperti menampilkan stok minimal barang, dan proses edit, delete, tambah 
barang pun dapat dilakukan dengan cepat serta dapat menampilkan informasi jumlah barang keluar dan barang masuk serta laporan yang dibutuhkan oleh pihak manajemen.

Penggunaan sistem informasi persediaan barang yang akan penulis rancang ini merupakan solusi yang tepat untuk mengatasi masalah tersebut. Sistem informasi persediaan barang berbasis web pada bagian gudang dibuat dengan menggunakan bahasa pemrograman $P H P$ dan $M y S Q L$ untuk mengelola databasenya dan mampu merekam seluruh data persediaan barang.

\section{RANCANGAN SISTEM YANG DIUSULKANDAN IMPLEMENTASI}

\subsection{Rancangan Sistem yang diusulkan}

Untuk menganalisa sistem yang diusulkan pada penelitian ini digunakan Program Visual Paradigm For UML 6.4 Enterprise Edition untuk enggambarkan Usecase Diagram, Clas Diagram, Sequance Diagram, State Chart Diagram, dan Activity Diagram.

\subsubsection{UseCase Diagram yang di Usulkan}

\section{a. Usecase Administrator}

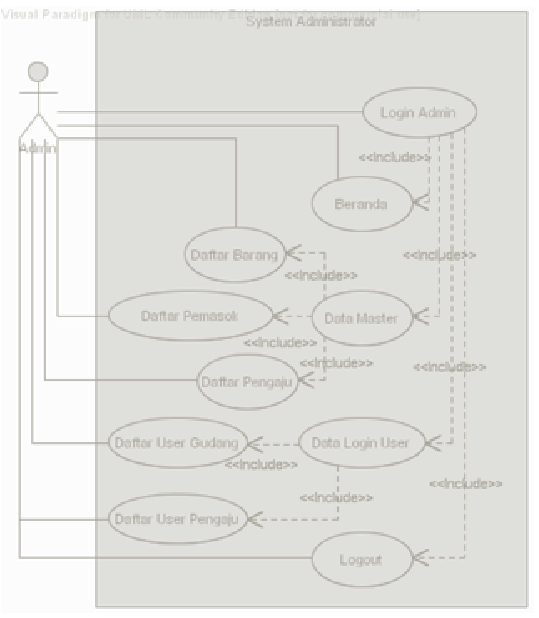

Gambar 4.1
Tampilan Usecase Diagram Administrator

Berdasarkan gambar Usecase Diagram yang diusulkan terdapat :

a. Sistem yang mencakup keseluruh persediaan barang.

b. 3 Actor diantaranya : Bagian Gudang, Pengaju dan Admin

b. Usecase Bagian Gudang

\section{Gambar 4.2}

Tampilan Usecase Diagram Bagian Gudang

Berdasarkan gambar Usecase Diagram yang diusulkan terdapat :

a. Sistem yang mencakup proses persediaan dan permintaan barang apabila stok barang berkurang dan membuat hasil laporan barang.

b. $\quad 4$ Actor diantaranya : Bagian Gudang, Pengaju, Pemasok dan Kadin.

\section{c. Usecase Pengaju}

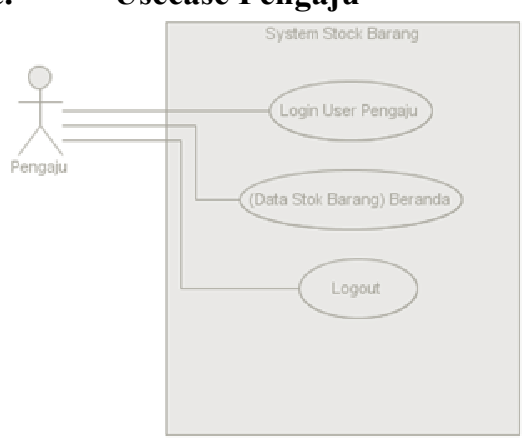

Gambar 4.3

Tampilan Usecase Diagram Pengaju 
Berdasarkan gambar Usecase Diagram yang diusulkan terdapat :

a. Sistem yang mencakup proses persediaan stok barang apabila da kekurangan barang.

4.2.2. Class Diagram yang Diusulkan pada Penyediaan Barang Dinas Pendapatan Daerah.

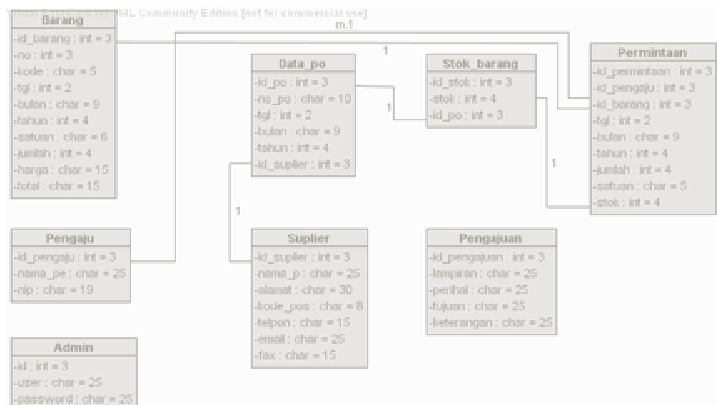

Gambar 4.4

Tampilan Class Diagram Yang diusulkan pada Penyediaan Barang Dinas

Pendapatan Daerah

4.2.3 Sequance Diagram Persediaan Barang Dinas Pendapatan Daerah

a. Sequence Diagram Pengaju

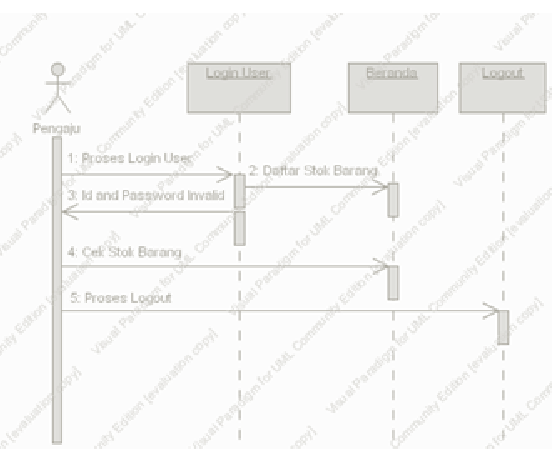

Gambar 4.5 Tampilan Class Squence

Pengaju

$\begin{array}{llr}\text { 4.2.4 State Chart } & \begin{array}{r}\text { Diagram } \\ \text { Persedian }\end{array} \\ & \text { Administrator } \\ \text { Barang } & \end{array}$

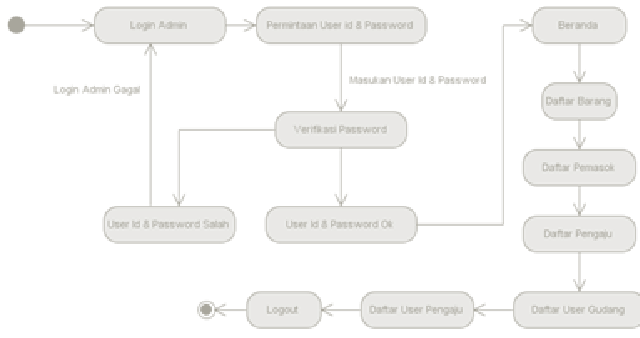

Gambar 4.6 Tampilan State Chart Diagram Administrator

\subsubsection{State Chart Diagram Bagian} Gudang Persedian Barang

Gambar 4.7 Tampilan State Chart Diagram Bagian Gudang

\subsubsection{State Chart Diagram Pengaju}

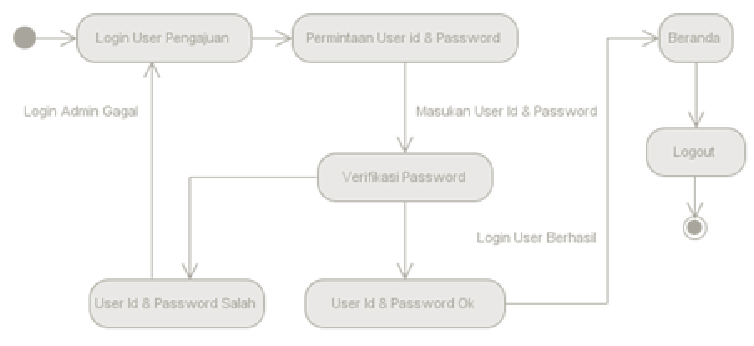

Gambar 4.8

Tampilan State Chart Diagram Pengaju

4.2.7 Activity Diagram Administrator 


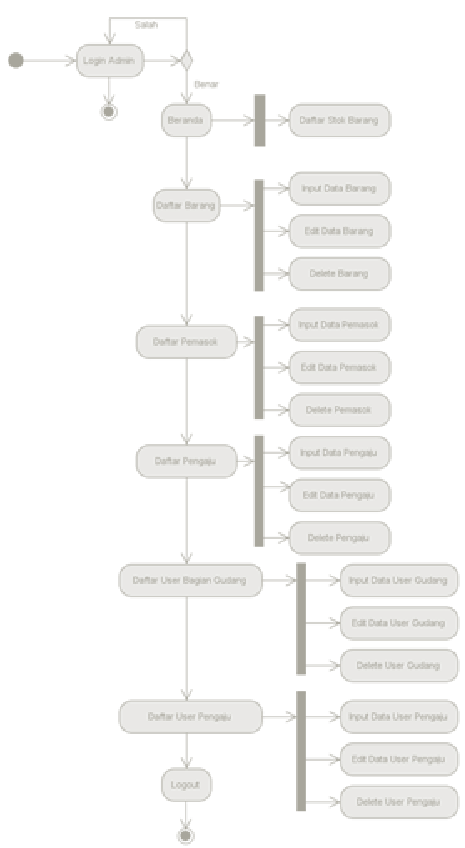

Gambar 4.9

Tampilan Activity Diagram Administrator

\subsubsection{Activity Diagram Bagian \\ Gudang}

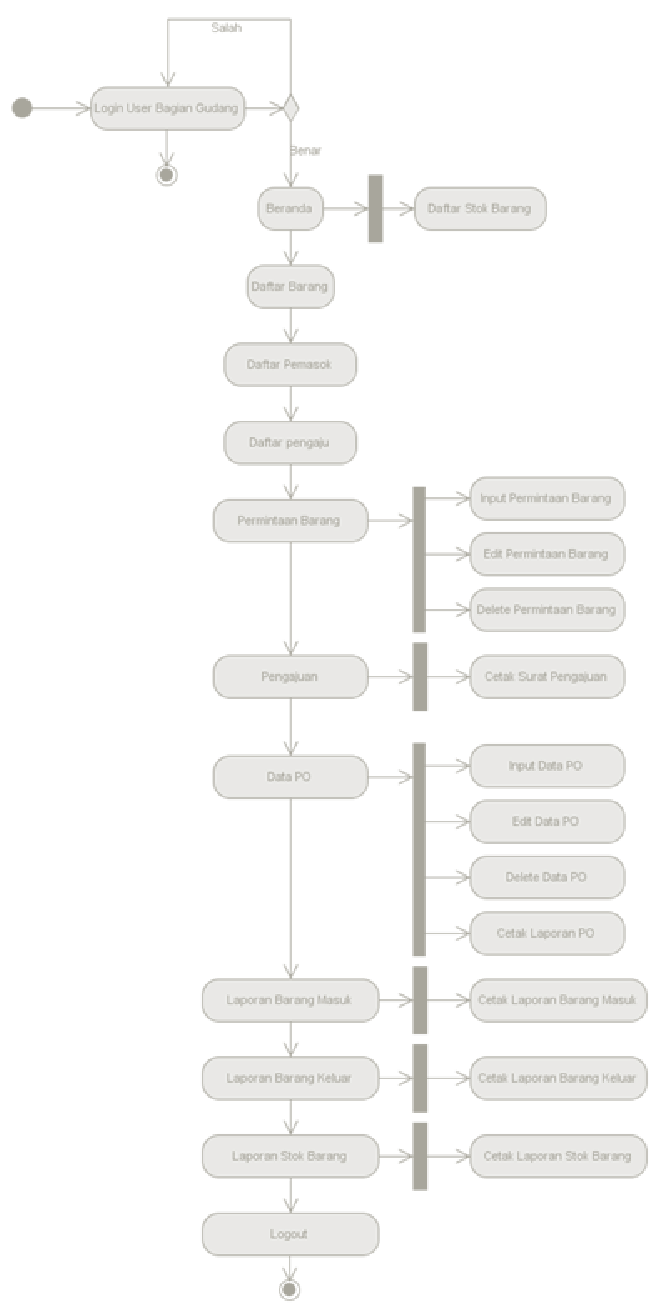

Gambar 4.10

Tampilan Activity Bagian Gudang

\subsubsection{Activity Diagram Pengaju}

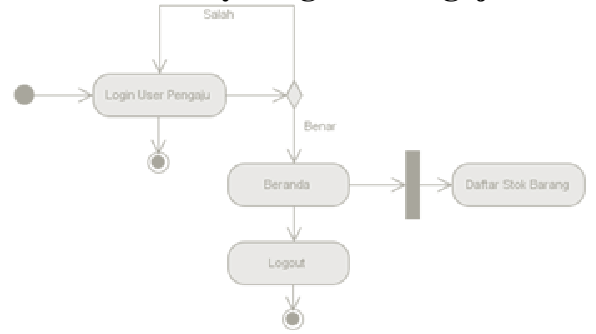

Gambar 4.11

Tampilan Activity Pengaju 


\subsection{Implementasi Sistem}

\section{Tampilan Menu Login}

Untuk dapat mengakses Sistem

Komputerisasi Persediaan Barang pada Bagian Gudang Dinas Pendapatan Daerah Kabupaten Tangerang, pada windows address Mozilla Firefox ketikkan alamat link yang dituju yaitu http://localhost/bella/index.php maka akan tampil layar pembuka yang merupakan tampilan awal website Persediaan Barang pada Bagian Gudang Dinas Pendapatan Daerah Kabupaten Tangerang sebagai berikut:

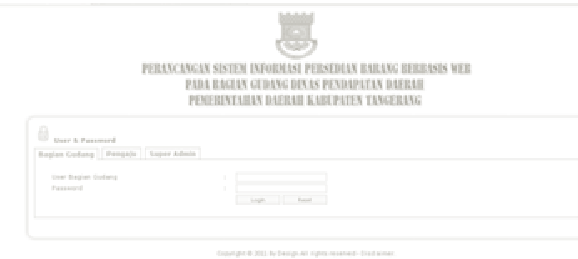

Gambar 4.12 Tampilan Menu login

Pada tampilan menu loginini digunakan untuk masuk ke halaman admin yang berisikan menu-menu pilihan yang akan digunakan oleh Bagian gudang, Pengaju, Maupun Super Admin tanpa dapat diketahui oleh orang lain.

\section{Beranda}

\section{Menu Halaman Utama /}

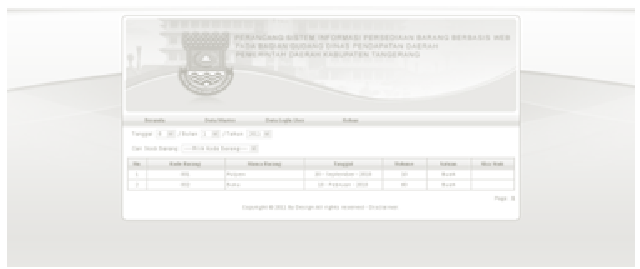

Gambar 4.13 Tampilan Menu Halaman utama atau Beranda

Halaman ini berisi informasi barang dan sisa stok yang update berdasarkan transaksi pembelian dan pengeluaran barang.

3. Menu Tambah Barang

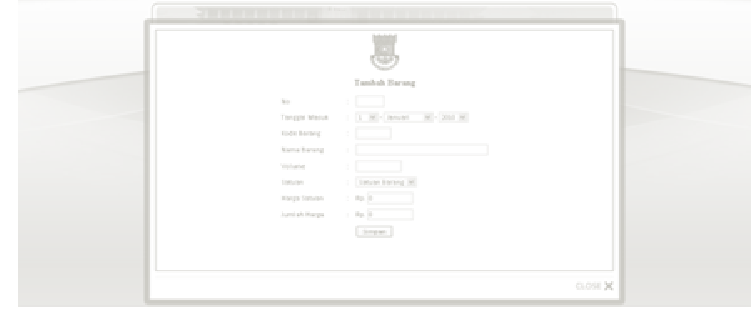

Gambar 4.14 Tampilan Menu tambah Barang

Halaman ini berisikan form tambah jenis barang baru yang terdiri dari atribut kode barang, nama barang, volume, satuan, harga satuan dan jumlah harga.

\section{Menu Daftar Stok}

\section{Barang}

Gambar 4.15 Tampilan Menu Daftar Stok Barang

Pada menu ini menampilakan daftar stok barang untuk informasi pada bagian gudang.

\section{Menu Tambah Pemasok}

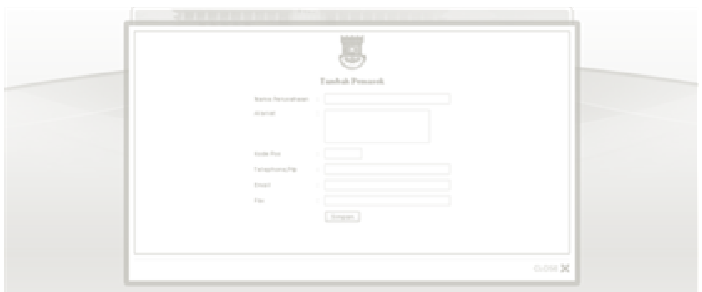

Gambar 4.16 Tampilan Menu Tambah Pemasok

Pada menu ini berisikan halaman form tambah pemasok yang di dalam nya terdapat nama perusahaan, alamat, telpon dan email.

6. Menu Daftar Pemasok 


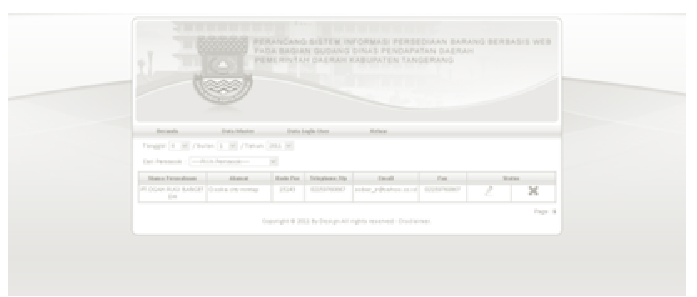

Gambar 4.17 Tampilan Menu Daftar Pemasok

Menu ini berisikan halaman daftar nama pemasok yang di input dari form pemasok.

7. Menu Tambah Pengaju

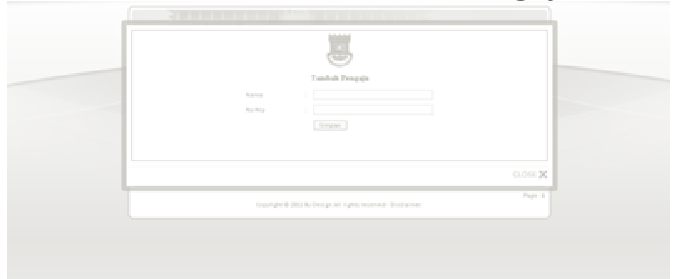

Gambar 4.18 Tampilan Menu Tambah Pengaju

Menu ini berisikan halaman form tambah pengaju yang atributnya berisi nama dan Nip.

8. Menu Daftar Pengaju

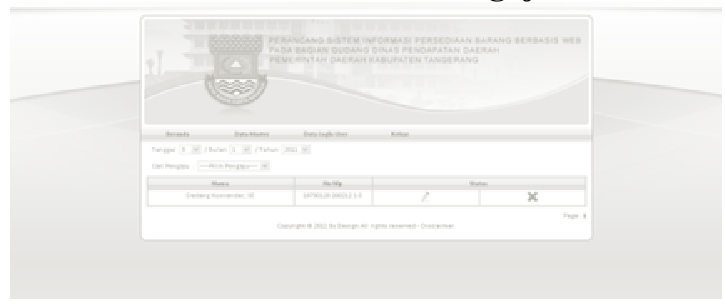

Gambar 4.19 Tampilan Menu Daftar Pengaju

Menu ini berisikan halaman daftar pengaju yang di input dari form tambah pengaju yang bisa dihapus dan ubah.

\section{Menu Permintaan}

\section{Barang}

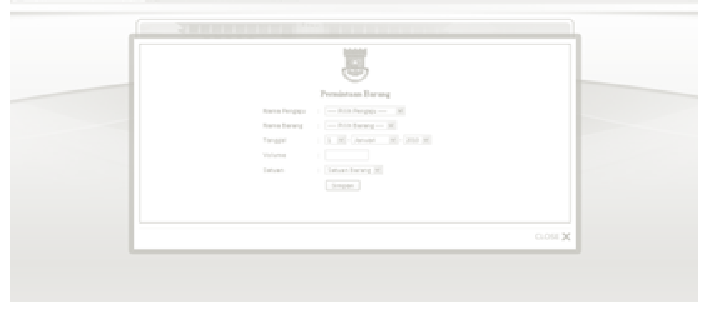

Gambar 4.20 Tampilan Menu Permintaan Barang

Tampilan ini berisikan halaman input permintaan barang yang berisi atribut nama pengaju, nama barang, tanggal, volume dan satuan barang.

\section{Menu Daftar}

\section{Permintaan Barang}

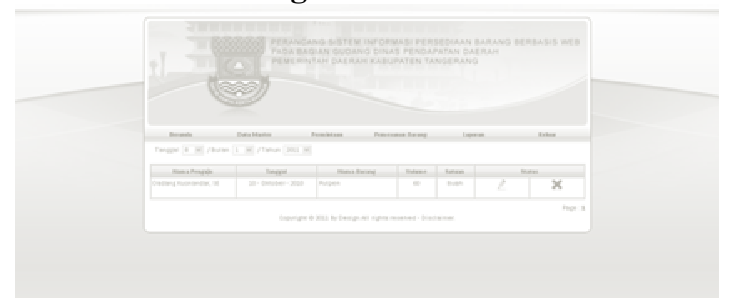

Gambar 4.21 Tampilan Menu Daftar PermintaanBarang

Menu ini berisi nama pegawai yang meminta barang dan jumlah barang yang sudah di input pada form permintaan barang.

\section{Barang}

\section{Menu Pengajuan}

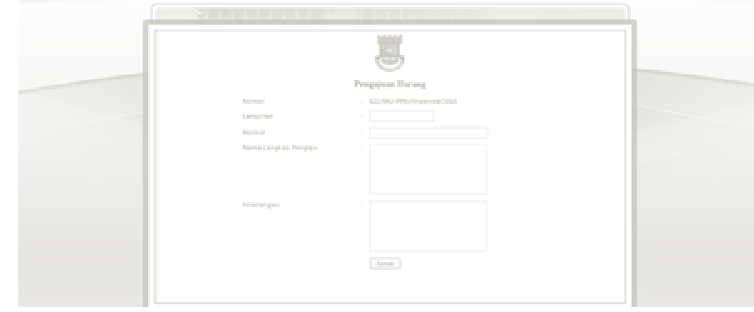

Gambar 4.22 Tampilan Menu Pengajuan Barang

Pada menu pengajuan barang atribut lampiran, perihal, nama lengkap pengaju dan keterangan. Bertujuan untuk mengajukan permintaan pembelian barang kepada stakeholder atau kadin.

\section{Menu Data PO}

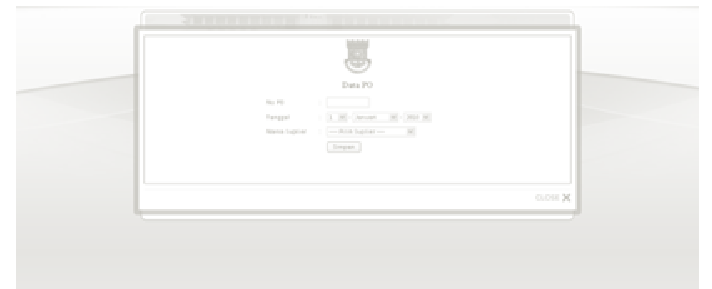

Gambar 4.23 Tampilan Menu Data PO Menu data PO memiliki atribut no PO, tanggal dan pilih supplier.

\section{Menu Daftar Data PO}


Gamabar 4.24 Tampilan Menu daftar data PO

Pada menu ini terdapat semua data PO yang sudah di input pada form data PO.

\section{Menu Cetak PO}

Gambar 4.25 Tampilan Menu Cetak PO Pada menu cetak PO adalah hasil pilihan pada menu daftar PO.

\section{Menu Laporan Barang}

Masuk

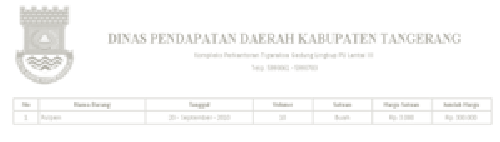

Gambar 4.26 Tampilan Menu laporan

Barang Masuk

Pada menu laporan barang masuk adalah laporan bulanan yang dapat di cetak untuk di berikan pada stakeholder atau kadin.

15. Menu Laporan Barang

\section{Keluar}

DINAS PESDAPATAN DAERAH KABUPATEN TANGERANG

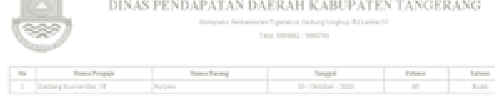

Pada menu laporan barang keluar dapat di cetak guna memenuhi laporan bulanan pada stakeholder atau Kadin.

\subsection{Kesimpulan}

\section{PENUTUP}

Berdasarkan hasil penelitian dan pengamatan yang telah dilakukan pada sistem persediaan barang pada bagian gudang Dinas Pendapatan Daerah Pemda Kabupaten tangerang, maka didapatkan beberapa kesimpulan yaitu :

1. Pada sistem persediaan barang yang berjalan pada saat ini belum terkontrol dengan baik. Karena sulitnya bagian gudang untuk mengetahui persediaan barang yang ada di gudang, karena data yang ada pada komputer belum tentu sesuai dengan data fisik atau barang yang tersedia di gudang. Sehingga setiap ada permintaan dari pengajuan, bagian gudang harus melakukan pengecekan stok barang terlebih dahulu ke gudang.

2. Sistem pengolahan data belum terkomputerisasi dengan baik, seperti dalam hal pemasukan data dan pembuatan laporan persediaan barang. Dikarenakan pada pengolahan data dan pembuatan laporan masih menggunakan microsoft exel.

3. Karena pembuatan laporan masih menggunakan microsoft exel membuat pegawai pada bagian gudang membutuhkan waktu yang lama untuk menyelesaikannya, sehingga stakeholder mengalami kesulitan dalam mendapatkan informasi laporan persediaan barang.

\subsection{Saran}

1. Dengan adanya sistem persediaan barang berbasis web, bagian gudang tidak perlu mengecek barang langsung ke gudang, cukup mengecek melalui sistem persediaan barang, sehingga lebih efektif.

Gambar 4.27 Tampilan Menu Laporan

Barang Keluar 
2. Dengan adanya sistem persediaan barang berbasis web, mempermudah pegawai pada bagian gudang untuk proses pemasukan data dan membuat laporan bulanan, karena sistem yang akan berjalan menjadi lebih baik.

3. Dengan adanya sistem persediaan barang, bagian gudang tidak perlu lagi menggunakan microsoft exel, sehigga waktu yang di butuhkan untuk pembuatan laporan persediaan barang kepada stakeholder, menjadi lebih singkat.

\section{DAFTAR PUSTAKA}

1. Jogiyanto H.M, "Sistem Informasi Berbasis Komputer" Penerbit Andi Yogyakarta 1999

2. Jogiyanto H.M, "Analisis Dan Desain Sistem Informasi" Penerbit Andi Offset 2001.

3. Bimo Sunartrihartono, "Website (situs web) ” Jakarta : Erlangga 2002

4. Rangkuti, Freddy (2004) Manajemen Persediaan, Aplikasi dibidang bisnis, edisi 2, cetakan 6, PT. Raja Grafindo Persada.

5. Modul bagian organisasi setda Kab. Tangerang, 2008.

6. Edi Purwono,"Tahap Perancangan Sistem" Yogyakarta Andi Offset 2002.

7. Fowler Martin, "Uml Distilled Ed. I" Penerbit Andi Publiser Terbitan 10 Januari 2005.

8. Endy Muhardin "Macromedia Firework" Penerbit Artivisi Intermedia 2003.

9. Mark Ade Syukur, "Konsep PHP" Jakarta : Erlangga 1990.

10. Abdul Kadir "Dasar Pemograman $W e b$ Dinamis". Penerbit Andi Yogyakarta 2002

11. AlbertV Dian Sano "24 Jam Menguasai HTML, JSP Dan MySQL" Penerbit Andi Yogyakarta 2003.

12. Endy Muhardin, "Belajar macromedia Dreamweaver" Penerbit Artivisi Intermedia 2003.

13. Literature Review, Eka sri sumartini (2008), Perancangan Sistem Informasi
Stok Barang Berbasis Web Pada Perguruan Tinggi Raharja.

14. Literature Review, Laela Fithriasari (2008), Perancangan Sistem Informasi Persediaan Barang Pada Gudang Lokal PT. Indah Jaya Textile Industry.

15. Literature Review, Umaidi (2008), Perancangan Sistem Informasi Persediaan Barang PT. Surya Renggo. 